\title{
Özel Eğitim Kurumlarında Çalışan Öğretmenlerin Çocuk İhmal ve İstismarına İlişkin Bilgi ve Farkındalık Düzeylerinin İncelenmesi ${ }^{1}$
}

\author{
DOI: 10.26466/opus.518214 \\ * \\ Arif Toydemir ${ }^{*}-$ Erkan Efilti ${ }^{* *}$ \\ * Öğr.Gör, Selçuk Üniversitesi, Sağlık Hizmetleri Meslek Yüksekokulu, Selçuklu/ Konya /Türkiye \\ E-Posta: toydemira@hotmail.com \\ ORCID: 0000-0002-3881-2501 \\ ** Dr. Öğr. Üyesi, Necmettin Erbakan Üniversitesi, Ahmet Keleşoğlu Eğitim Fakültesi, Meram/ \\ Konya/ Türkiye \\ E-Posta: efilti71@gmail.com \\ ORCID: 0000-0003-1158-5764
}

\section{Öz}

Bu araştırma, özel eğitim kurumlarında çalışan öğretmenlerin, çocuk ihmal ve istismarına ilişkin bilgi ve farkındalık düzeylerini belirlemek amacıyla yapılmıştır. Bu genel amaç doğrultusunda araştırma, Konya ili merkez ilçelerinde bulunan, özel eğitim kurum/okullarında görev yapan 18 kadın 13 erkek olmak üzere toplam 31 öğretmen üzerinde gerçekleştirilmiştir. Bu araştırmada amaçörnekleme yöntemi kullanılmıştır. Araştırmada, katılımcıların çocuk ihmal ve istismarına ilişkin görüş, tutum ve deneyimlerini derinlemesine belirlemek amacı ile nitel araştırma yöntemi tercih edilmiştir. Nitel araştırma kapsamında, katılımcılar hakkında birçok bilgiye ulaşılmasını ve konunun farklı boyutlarıla incelenmesini să̆layacă̆̆ndan, görüşme tekniği kullanılmıştır. Görüşmeler sonucunda elde edilen veriler, betimsel analiz yöntemi ile belli tema ve başlıklar altında toplanarak anlamlı hale getirilmiş ve yorumlanmıştır. Araştırma sonucunda; özel eğitim kurumlarında çalışan öğretmenlerin, kendilerini ve meslektaşların çocuk hakları, çocuk ihmal ve istismarı konusunda duyarl gördükleri fakat bilgilerinin yetersiz olduğu, ihmal ya da istismarı tanılamada yeterli olmadıkları, ihmal ya da istismar vakasıyla karşılaşmaları durumunda bildirimde bulunacakları, okul ortamlarında konuya yönelik yeterli bilgilendirme çalışmalarının yapılmadı̆̆ı sonucuna ulaşılmışıır. Bu sonuçlar doğrultusunda öneriler geliştirilmiştir.

Anahtar Kelimeler: Çocuk ihmal ve istismarı, çocuk hakları, özel eğitim

\footnotetext{
${ }^{1}$ Bu çalışma, Dr. Öğr. Üyesi Erkan Efilti danışmanlığında Arif Toydemir tarafından Konya Necmettin Erbakan Üniversitesi, Eğitim Bilimleri enstitüsü, Özel Eğitim Anabilim dalında Yüksek Lisans Tezi olarak hazırlanmıştır.
} 


\title{
Examination of The Knowledge And Awareness Levels of Teachers Working in Special Education Institutions About Child Neglect and Abuse
}

\begin{abstract}
This research was conducted to determine the level of knowledge and awareness of teachers working in special education institutions about child neglect and abuse. For this general purpose, the study was conducted on a total of 31 teachers, 18 women and 13 men working in special educational institutions / schools in central districts of In this research, the purposed sampling method was used. Konya. In this research, qualitative research model was preferred to determine the views, attitudes and experiences of the participants about child neglect and abuse. As part of the qualitative research, the interview technique was used as it would provide access to a lot of information about the participants and to examine the subject in different dimensions. The data obtained as a result of the interviews were collected and interpreted under certain themes and headings with descriptive analysis method. As a result of research; working in special education settings teachers, themselves and their colleagues on children's rights, child abuse and neglect sensitive about they saw, but the information is insufficient, they are not sufficient in diagnosing abuse or neglect, cases of abuse or neglect will provide notification in the event of encountering, and in the school environment concluded that sufficient information regarding the subject of the study is not done. Recommendations have been developed in line with these results.
\end{abstract}

Keywords: Child, neglect and abuse, child rights, special education. 


\section{Giriş}

Modern devlet anlayışı içerisinde bir toplumun refah düzeyini belirleyen en temel unsur, toplum içinde yaşamakta olan bireylerin yaşam kaliteleridir. Toplumların, yaşam kalite ve düzeylerini yükseltebilmeleri için en güvenilir ve sağlıklı yatırım, çocuklara yapılan yatırımdır. Toplumların geleceği, çocukların bedenen, ruhen, ahlaken ve fikren sağlıklı gelişmesine ve eğitilmesine bağlıdır. Toplumların yarınlarını sağlam ve sağliklı temeller üzerine oturtabilmeleri için çocukların bedensel ve ruhsal sağlıklarının korunması ve eğitilmeleri gerekliliği genel kabul gören bir gerçektir ( Kocaer, 2006). Modern devlet aynı zamanda sosyal devlettir. Sosyal devlet; devletin halkını ve geleceğini korumak için ihtiyaç duyulan alanlarda koruma programları geliştirmesi ve uygulamasıdır (Yıldırım Doğru, Saltalı, Konuk Er ve Budak, 2014). Çocuklar için geliştirilecek olan her türlü politika ve uygulamaların temelinde, her çocuğun bağımsız bir birey olarak kabul edilmesi, ekonomik ve sosyal haklardan olabildiğince yararlanması ve daha da önemlisi onların temel hak ve hürriyetlerden yoksun birakılmaması gerekmektedir (Aral ve Gürsoy, 2001; Kocaer, 2006).

Ebeveynlerin evlilik birlikteliklerinin bir ürünü olarak kabul edilen çocuklar, eşleri birbirine bağlayan, aile birliğinin sağlanmasında etkin bir unsur olarak görülen, bir ailenin sahip olmayı isteyeceği ödül olarak kabul edilmektedir (Ataman, 2003). Çocuğun eski çağlardaki değeri ile günümüzdeki değeri karşılaştırıldığında çocuk haklarının tarihi gelişimi; çocuğun üzerinde serbestçe tasarruf edilebilir, devir ve terk edilebilir, hatta öldürülebilir bir "nesne" olmaktan çıkarılıp, haklara ehil, kişilik sahibi bir "özneye" dönüştürülmesinin serüveni olarak özetlenebilir (Çelik, 2014).

Çocukların sağlıklı şekilde yetişmeleri, nitelikli, kişilik ve karakterlerinin kendilerine özgü şekilde gelişmesini sağlamak, karmaşık ve zahmetli bir süreçtir. Bu süreçte ebeveynler, yetişkinler, öğretmenler ya da çeşitli kurumlar, bilerek ya da bilmeyerek çocuğun hak ve özgürlüklerini ihlal etmekte, gelişimine olumsuz etkide bulunacak davranışlar sergilemektedir. Çocuk, sahip olduğu özelliklerden dolayı korunmaya en çok muhtaç olan grup olarak kabul edilir (Taş, 2017). Çocukların özellikle bedenen zayıf olmaları, kendini güçlü gören tarafından suiistimal 
edilmesine sebep olmaktadır. Güçlü olan zayıf olana hükmetmek istemektedir. Engellilik de toplumlarda zayıflık olarak görülmekte ve engelli çocuklar da aynı suiistimale uğramaktadırlar.

Çocuğun yüksek yararının korunması hedeflenerek, ulusal ve uluslararası alanda birçok yasal düzenleme yapılmıştır. Bu düzenlemelerle çocuğun korunmasının güçlendirilmesi, hak ve özgürlüklerinin güvence altına alınması sağlanmaya çalışılmıştır. Ancak tüm bu yapılanlara rağmen çocuk istismar ve ihmallerinin devam ettiği görülmektedir (Taş, 2017). İhmal ve istismar olayları günümüz çocuklarının yaşadığı önemli sorunlardan biri olarak karşımıza çıkmaktadır. Bu sorunun tarihi ilkçağa kadar uzanmakta, günümüzde de boyutları ve karmaşıklığı artarak devam etmektedir. Dünyada ve Türkiye'de ihmal ve istismarlarm sıklıkla yaşanmasına karşın birçok devletin istismarın önlenmesinde ve istismar gören çocukların tedavisini sağlamada yetersiz kaldığ bilinmektedir (Erol, 2007). Çocukların temel hak ve özgürlüklerinin tam olarak bilinmemesi, toplumsal kesimler tarafından yeteri kadar içselleştirilememesi veya cezaların caydırıcı olmayışı çocukların çeşitli ihmal ve istismarlara uğramalarına sebep olabilmektedir (Sağır, 2013). Bu ihmal ve istismarlar sonucunda çocuklar, bedensel, duygusal, zihinsel ve sosyal açıdan farklı derecelerde olumsuz etkilenmekte ve örselenmektedirler.

Çocukların, yetişkinlerden farklı özelliklere sahip oldukları ve bir birey olarak görüldüğü, yaşatılmalarının, gelişmelerinin ve korunmalarının uluslararası bağlamda ilk kez temel ilke olarak ele alınması 5 maddelik "Cenevre Çocuk Hakları Bildirgesi" (1924) ile mümkün olmuştur. Bildirge daha sonra "BM Çocuk Hakları Sözleşmesi" (1989) olarak, uluslar arası sözleşme haline gelmiştir. Sözleşmenin en önemli özelliklerinden biri; çocuğun, hakların öznesi olarak kabul edilmesidir (Usta,2012). Çocuk hakları ve çocuk refahı konularında modern anlayıştaki batı ülkelerinde, önemli ölçüde yol alındığı gözlenmektedir ki diğer ülkeler onları takip etmekte, onların oluşturduğu uluslararası kuruluşlara üye olmakta ve onlardan fayda ummaktadırlar. Türkiye'deki duruma bakıldığında çocuk istismarına belli ve nispi ölçülerde cezalar söz konusu olmasına rağmen, çocuk ihmallerinin bir suç teşkil etmediği görülmekte hatta hangi davranışların ihmal kapsamına girip girmediği bile bilinmemektedir. Dünyada çocuk istismarı \% 1 ila \% 10 arasında değişirken Türkiye'de bu oran 
\%10 ila \% 53 arasında değişmektedir (Yıldırım Doğru ve ark, 2014). Çocuğun ihmal ve istismarı onun duygusal yaşantısını ve kişiliğini derinden etkilemekte ve gelecek yaşantısında sağlıksız bir kişilik geliştirmesine neden olabilmektedir. Çocukta, kronik bir rahatsızlık ya da doğuştan gelen bir engeli varsa anne babanın çocuğu kabul etmeleri de güçleşmektedir. Bu tür durumlar ise anne babanın çocuğu örselemesine neden olmaktadır (Hoşoğlu, 2009).

İstismar, gelişimini tamamlamamış bir bireye yönelik davranışları tanımlamak için kullanılan bir kavram olduğundan engelli bireylerin büyük oranda risk altında olduğu görülmektedir. Çünkü onlar gelişimlerini farklı nedenlerle tamamlamada gecikme yaşayan ve bunun için destek alması gereken bireylerdir (Bulut ve Karaman, 2018). Çocuk hakları sorunları kapsamında yer alan kesimlerden biride zor koşullardaki çocuklardır. Bunlar sokak çocukları, istismar edilen çocuklar, afet ve göçe maruz kalan çocuklar ve engelli çocuklardır (Polat, 2001). Türkiye de ve dünyada çocuk hakları ihlallerini ve çocuk istismarını önlemeye yönelik kapsamlı çalışmalar yapılması gerekmektedir. Diğerlerine göre daha dezavantajlı olarak nitelendirdiğimiz özel eğitim gereksinimi olan engelli çocukların ihmal ve istismar açısından risk gruplarının başında geldiği bilinmektedir. Çocuk ihmal ve istismarlarının önlenmesi, zor, karmaşık ve zaman gerektiren bir iştir. Tüm toplum katmanlarının destek sağlaması gerekir. Bu doğrultuda çocuklarla yakın etkileşim halinde olan öğretmenlerin konuya ilişkin farkındalıklarının arttırılması, gerek durumun tespit edilmesi gerekse erken dönemde müdahale edilmesi açısından oldukça önem taşımaktadır (Tugay, 2008). Bu araştırmada, "özel eğitim kurumlarında çalışan öğretmenlerin çocuk ihmal ve istismarına ilişkin bilgi ve farkındalık düzeylerinin incelenmesi" bu çalışmanın ana problemini oluşturmaktadır. Özellikle bu alanda yapılacak olan bilimsel araştırmaların, çocuk haklarına yönelik yapılacak çalışmalara, atılacak adımlara ve belirlenecek politikalara katkı sağlayacağı düşünülmektedir.

Çalışmanın amacı, özel eğitim kurumlarında çalışan öğretmenlerin çocuk ihmal ve istismarı konusundaki bilgi ve farkındalık düzeylerinin nitel bir çalışma ile ortaya konulmasıdır. Bu amaca paralele olarak, özel eğitim kurumlarında çalışan öğretmenlerin ihmal ve istismar konusunda, bilgi durumları, bu bilgileri nerede ve nasıl elde ettikleri, kurumlarında ne tür çalışmalar yapıldığı, ihmal ve istismarın belirtilerini nasıl 
anladıkları, istismarın nedenleri konusundaki düşünceleri, olayla karşılaşma durumunda tutumlarının ne olacağı ve istismarı önleme konusundaki önerileri nelerdir? Sorularına cevap aranmıştır.

\section{Yöntem}

Bu çalışmada araştırmanın amacına uygun olarak nitel araştırma yöntemi kullanılmıştır. Nitel araştırma, "gözlem, görüşme ve doküman analizi gibi veri toplama araçlarının kullanıldığı, olayların ve algıların, gerçekliğe uygun şekilde ortaya konduğu" araştırma yöntem ya da modelidir. Nitel araştırmalarda sayılardan ve yüzdelerden öte anlamlar, bakış açıları ve değerlendirmeler ön plandadır. Geçerlilik ve güvenilirliğin sağlanmasında araştırmacının tutumu daha ön plandadır. Nitel araştırmalarda verilerin toplanması, analiz, yorum ve değerlendirmeleri araştırmacının kişisel değerlendirmelerinden bağımsız değildir (Yıldırım ve Şimşek, 2013). Bu çalışmada nitel araştırma yöntemlerinden olgubilim deseni kullanılmıştır. Olgubilim (fenomenoloji/phenomenology) deseni farkında olduğumuz ancak derinlemesine ve ayrıntılı bir anlayışa sahip olmadığımız olgulara odaklanmaktadır (Yıldırım ve Şimşek, 2013).

\section{Çalışma Grubu}

$\mathrm{Bu}$ araştırmanın konusunun belirlenmesinde, çocuk ihmal ve istismarı alanında daha az çalışılan alan olarak gördüğümüz özel eğitim kurumlarında çalışan öğretmenlerin bu konuya bakışlarının belirlenmesinin önemi etkili olmuştur. Araştırmanın yöntemi, modeli ve veri toplama aracına uygun yeterli olacağ 1 düşünülen belli sayıda katılımcı seçilmiş ve bu katılımcılar, araştırmanın çalışma grubunu oluşturmuştur. Örnekleme seçiminde amaçlı örnekleme yöntemlerinden kolay ulaşılabilir (convenient) durum örneklemesi kullanılmıştır. Çalışma grubu; "hedef evren" "erişilebilir evren" olarak da adlandırılır (Akbulut, 2010). Çalışma grubu, Konya ili merkez ilçelerinde bulunan resmi özel eğitim okulu ve merkezlerde çalışan 31 öğretmenden oluşmaktadır. Katılımcıların kişisel özellikleri incelendiğinde, cinsiyet açısından 18 (\% 68,2)'nin kadın, 13 (\% $31,2)^{\prime}$ sinin erkek. Yaş durumuna göre 12' sı 20-29 yaş aralığında, 11' i 3039 yaş aralığında, 6'i 40-49 yaş aralığında ve 2 kişide 50 yaş üstünde dir. 
Medeni durum açısından 21 tanesi evli 10 tanesi ise bekar. Mesleki kıdemleri açısından 12 tanesi 1-5 yıl, 10 tanesi 6-10 yıl, 6 tanesi 11-15 yıl ve 3 tanesi de 16 yıl üstü mesleki tecrübeye sahip oldukları görülmektedir.

\section{Veri Toplama Aracı}

Nitel araştırmalar, insanların deneyimlerini olduğu gibi aktarmayı ve açıklamayı amaçlar. Bu araştırmada da amaca yönelik olarak, nitel araştırmalarda sıklıkla kullanılan, görüşme tekniği veri toplama aracı olarak belirlenmiştir. Görüşme, araştırmanın konusuna yönelik, araştırmacı ile çalışma grubunda yer alan, katılımcılar arasında soru-cevaba dayalı bir iletişim sürecidir. Bu süreç çeşitli iletişim araçları ile gerçekleştirilebileceği gibi sıklıkla yüz yüze yapılmaktadır. Yüz yüze uygulandığında görüşme, kişiyle birebir iletişim imkânı veren, katılımcı hakkında birçok bilgiye ulaşılmasını sağlayan ve konunun farklı boyutlarının da ortaya çıkarılmasına yardımcı olmaktadır. Doğru ve gereğine uygun şekilde yapılmak istendiğinde görüşme, sanılanın aksine zahmetli bir süreçtir (Yıldırım ve Şimşek, 2013).

Araştırmada kullanılan görüşme formu iki kısımdan oluşmuştur: kişisel bilgi formu ve görüşme türleri arasında yer alan yarı yapılandırılmış görüşme formudur. Yarı yapılandırılmış görüşme formu araştırmada, konunun çok farklı boyutlarının ortaya çıarılması, görüşmenin doğal akışında ilerlemesi ve araştırmacıya görüşmenin akışına göre hareket imkânı sağlamaktadır. Açık uçlu sorulardan oluşan yarı yapılandırılmış görüşme formu 6 ana sorudan oluşmuştur

1. Çocuk hakları, çocuk koruma kanunu, çocuk hakları sözleşmesi, çocuk ihmal ve istismarı ile ilgili bilgi durumunuz nedir, kendinizi yeterli görüyor musunuz, sahip olduğunuz bilgileri nasıl elde ettiniz, bilgi verir misiniz?

2. Çocuk ihmal ve istismarına yönelik okul ya da kurumunuzda ne tür çalışmalar yapıldı/yapılıyor, bilgi verir misiniz?

3. Çocukların, ihmal ve istismara uğramalarının nedenlerinin neler olduğunu düşünüyorsunuz?

4. Bir çocuğun ya da öğrencinizin ihmal veya istismara uğradığını nasıl anlarsınız, belirtileri neler olabilir? 
5. Öğrencilerinizden birinin ihmal ya da istismara uğradığını fark ederseniz tutumunuz ne olur?

6. Çocuğa yönelik ihmal ve istismarların azaltılması için neler yapılması gerektiğini düşünüyorsunuz, önerileriniz var mı, varsa neler olabilir?

\section{Veri Toplama Süreci}

Veri toplama sürecinde katılımclara önce araştırmanın konusu ve amacı hakkında bilgi verilmiş ve olurları alınmıştır. Görüşmeler bazı okullarda müdür odasında, bazı okullarda öğretmenler odasında, bazılarında ise rehberlik odasında bire bir görüşmeler şeklinde gerçekleştirildi. Katılımcıların cevapları, jest, mimik ve vurguları dikkate alınarak özenle not edildi. Katılımcların anlattıklarından hareketle bazı soruların sırası değiştirilmiştir.

\section{Verilerin Analizi ve Değerlendirilmesi}

Görüşmeler yoluyla elde edilen verilerin analizinde, betimsel analiz yöntemi kullanılmıştır. Betimsel analiz, bir olayın neden oluştuğu ve kimleri ilgilendirdiği sorularına cevap vermek üzere elde edilmiş verilerin daha önceden belirlenmiş temalara göre özetlenmesi ve yorumlanmasını içeren nitel veri analizi türüdür.

Betimsel analizde önce bir çerçeve oluşturulur, sonra verilerin hangi kavram ya da temalar altında düzenleneceği belirlenir ve hazırlanmış olan çerçeveye göre veriler okunur, düzenlenir ve işlenir. Son aşamada ise bulgular açıklanır, ilişkilendirilir ve anlamlandırılır (Şimşek ve Yıldırım, 2013).

Araştırmada kullanılan görüşme sorular; bilişsel, duyuşsal ve davranışsal olmak üzere üç boyut düşünülerek hazırlanmıştır. Görüşme formunda yer alan sorular, katılımcıların çocuk ihmal ve istismarı konusunda bilgi durumlarını bilişsel, tutum ve duyarlıkları duyuşsal ve karşılaşmaları durumunda nasıl davrandıkları ise davranışsal boyut olarak ele alınmıştır. Katılımcılardan elde edilen veriler önceden ya da araştırma sırasında belirlenen temalar altında toplanmış, bir bütünlük 
oluşturacak şekilde yeniden düzenlenmiş ve sistematik bir şekilde daha anlaşılır hale getirmek için tablolara dönüştürülerek yansıtılmıştır.

\section{Bulgular}

Tablo 1 incelendiğinde katılımcların \% 93,5'i ÇKK, ÇHS ve çocuk ihmal ve istismarı ile ilgili yeterli bilgiye sahip olmadıklarını belirtmişlerdir. Üniversite yaşamlarında konuyla ilgili ders ya da eğitim etkinliklerine katıldıklarını söyleyen katılımcıların oranı sadece \%16,1 dir. Öğretmenlerden sadece 3'ü, konuyla ilgili bireysel araştırma gereği duyduklarını bildirmişlerdir.

Tablo 1. Bilgi durumları ve hangi yolla elde ettiklerine dair bulgular

\begin{tabular}{lll}
\hline ÇKK, ÇHS ve çocuk ihmal ve istismarına yönelik bilgi durumları & $f$ & $\%$ \\
\hline Konuyla ilgili yeterli bilgiye sahip değilim & 29 & $\mathbf{9 3 , 5}$ \\
\hline Üniversitede konuyla ilgili dersler, seminer vb. aldım & 5 & $\mathbf{1 6 , 1}$ \\
\hline Konuyu bireysel olarak araştırma imkânım oldu & 3 & $\mathbf{9 , 6}$ \\
\hline ÇKK ve ÇHS duydum fakat yeterli bilgim yok & 27 & 87 \\
\hline Meslek yaşamında çeşitli eğitimlere katıldım & $\mathbf{1 0}$ & 32,2 \\
\hline ÇKK: Çocuk koruma kanunu. ÇHS: Çocuk hakları sözleşmesi & &
\end{tabular}

Katılımcıların \%87'si çocuk ihmal ve istismarında temel teşkil eden Çocuk Koruma Kanunu ve Çocuk Hakları Sözleşmesi'ni duyduklarını fakat içerikleri konusunda yeterli bilgiye sahip olmadıklarını söylemişlerdir. Ayrıca sadece \% 32,2'si meslek yaşamları boyunca doğrudan ya da dolaylı olarak konuyla ilgili eğitim, kurs, seminer vb etkinliklere katıldıklarını ifade etmişlerdir.

“....̈̈niversitede okurken gördüğ̈̈müz felsefe ve sosyoloji derslerinin içinde bu konular geçiyordu" (Ö22).

"cinsel istismarla ilgili seminere katıldım, hep cinsel istismar konularn anlatılıyor. fakat yeterli bilgiye sahip değilim" (Ö5).

“ ...10 yillı öğretmenlik yaşamımda, bu konuda herhangi bir etkinliğe katılmadım" (Ö21).

Tablo 2' de öğretmenlerin çalıştıkları kurumlarda, çocuk ihmal ve istismarı konusuna yönelik ne gibi çalışmalar yapıldı̆̆ı, kendilerinin katıldıkları çalışmalar olup olmadığı, öğrenci ve velilere yönelik ne gibi çalışmaların 
olduğu belirlenmeye çalışılmıştır. Öğretmenlerin sadece \%9,7'si şu an bulunduğu okulda öğretmenlere yönelik bilgilendirme çalışmaları yapıldığını, \% 90'ı herhangi bir çalışma yapılmadığını, \%29,2'si rehberlik servisi tarafından öğrenci, özelliklede velilere yönelik konuyla ilgili bilgilendirme çalışmaları yapıldığını ifade etmiştir.

Tablo 2. Katılımcıların çalıştıkları kurumlarda yapılan çalışmalara dair bulgular:

\begin{tabular}{lll}
\hline Okulunuzda konuyla ilgili ne tür çalışmalar yapıldı ya da yapılıyor. & $f$ & $\%$ \\
\hline Rehberlik servisi aile veya öğrencilere bilgilendirme yapıyor & 12 & 29,2 \\
\hline Öğretmenlere yönelik eğitim, kurs, seminer ya da bilgilendirme yapıldı & 4 & 9,7 \\
\hline Kendim konuyla ilgili çocuklara bilgi veriyorum. & 2 & 4,8 \\
\hline Konu ile ilgili, okul idaresi sürekli hatırlatma yapıyor & 14 & 34,1 \\
\hline
\end{tabular}

Katılımcı öğretmenlerden \%34,1'i okul idaresinin bu konuda sürekli hatırlatmalar yaptı̆̆ını söylemiştir. Ayrıca öğretmenlerin $\% 4,8$ 'i, konuyla ilgili kendilerinin sınıf içinde öğrencilere eğitim ve bilgi verdiğini ifade etmiştir.

“....okulda bu konuda hiçbir eğitim almadım, bir etkinliğe de katılmadım. Fakat bazı şeyler yapılabilir. Örneğin; Bu yıl çocuk istismarı ile ilgili bilinçlendirme yılı olmalı. 81 ilde aynı anda. Sadece kenar okullara değil, resmi özel, zengin, fakir her zümreye yönelik olmalı" (Ö30).

“....̈ğrencilere cinsel eğitim veriyorum. Rehberlik dersinde tacizden korunma konusu işlendi" (Ö8).

Tablo 3. İhmal ve istismarnn nedenlerine yönelik görüşlere dair bulgular:

\begin{tabular}{lcc}
\hline İhmal ve istismarın nedenleri konusundaki düşünceleri & $f$ & $\%$ \\
\hline $\begin{array}{l}\text { Ailenin ilgisizliği, eğitim seviyesinin düşük olması, yoksulluk, par- } \\
\text { çalanmış aile vb }\end{array}$ & 31 & 100 \\
\hline Çocuğun engelli olması & 18 & 58 \\
\hline Ahlaki bozulma, değerlerden uzaklaşma. & 4 & 12,9 \\
\hline Tv. Programları, diziler, internet, zararlı siteler vb. & 4 & 12,9 \\
\hline Çocuğun içe kapanı, özgüvensiz, çekingen olması gibi. & 3 & 9,6 \\
\hline Cezaların yetersizliği & 3 & 9,6 \\
\hline
\end{tabular}

Tablo 3 de istismarın nedenleri konusunda katılımcıların tümü (\% 100) ilk sırada ailenin yaşadığı yoksulluğu, eğitim seviyesinin düşüklüğünü, çocuğa karşı ilgisizliklerini görmektedir. Çocuğun engelli olması ise ikinci 
sirada (\% 58) daha sonra sirasiyla ahlaki bozulma ve değerlerden uzaklaşma (\% 12,9), televizyon programları ve internet (\% 12,9), çocuğun içe kapanık ve çekingen olması $(\% 9,6)$ ve cezaların yetersizliğini $(\% 9,6)$ belirtilmiştir. Çocuğun engelli olması cevabı katılımcıların "engelli çocukların istismara daha açık olduklarının, risk grubu içinde yer aldıklarını" vurgulamak açısından ifade ettikleri görülmüştür. Araştırmanın amac1nın, genel anlamda çocuk istismarı olduğu belirtilmesine rağmen çoğu katılımcı bunu engelli çocuklara yönelik bir çalışma olarak değerlendirmişlerdir.

“...günümüzde anne babaların psikolojileri bozuk olduğundan çocuk ihmalleri artıyor. Bazı durumlarda istismar olmamasına rağmen ailelerin psikolojisi bozuk olduğu için yersiz şikâyetlerde bulunuyorlar. Bu sebeple toplumda istismar yaygınmış gibi görünüyor. Ortaokul ve liselerde özellikle kız çocuklarının öğretmenlere yönelik senaryo uydurduklarmı, tuzak kurduklarmı düşünüyorum. Öğretmenlerin öğrencilere fiziksel şiddette bulunmalarl, mesleki yetersizliklerinden kaynaklanıyor. Otoriter tutumla sınıfa hâkim olmaya çalışıyorlar" (Ö3).

Tablo 4. Tanılamada yeterlilik ve farkındalı̆̆a dair bulgular:

\begin{tabular}{lcc}
\hline Tanılamada yeterlilik ve farkındalık & $f$ & $\%$ \\
\hline Fiziksel istismarı daha kolay anlarım; darp izi, morluk vb. & $\mathbf{2 9}$ & $\mathbf{9 3 , 5}$ \\
\hline Meslektaşlarım bu konuda duyarlı davranıyorlar. & $\mathbf{2 6}$ & $\mathbf{8 3 , 8}$ \\
\hline Davranışlarında ani değişiklik; içe kapanma, hırçınlık, utangaçlık & $\mathbf{2 4}$ & $\mathbf{7 7 , 4}$ \\
\hline Meslektaşlarım bu konuda yeterli bilgiye sahip değiller & $\mathbf{1 5}$ & $\mathbf{4 8 , 3}$ \\
\hline Karşılaşmadığım için fazla bilgim yok. & $\mathbf{1 8}$ & $\mathbf{5 8}$ \\
\hline
\end{tabular}

Tablo 4 de, ihmal ve istismarın belirtileri konusunda öğretmenlerin, \%93,5'i ilk sırada fiziksel istismara yönelik belirtileri darp ve morluklar sebebiyle daha kolay anlayabileceklerini ifade etmişlerdir. İstismarın psikolojik belirtileri olarak görülen, İçe kapanma, hırçınlık ve utangaçlık gibi belirtileri ise \%77,4'le ikinci sırada belirtmişlerdir. Görüşmeler sırasında, vakayla karşılaştınız mı? Sorusu yöneltilmiştir. Buna verilen cevaplarda 18 katılımcı (\% 58) vakayla karşılamadığı için fazla bilgi veremeyeceğini belirtmiştir. Yine görüşmenin akışı içerinde katılımcılara istismarı tanılama konusunda "meslektaşlarınızın bilgi ve duyarlılıkları hakkında ne düşünüyor musunuz? Sorusu yöneltilmiştir. Bu soruya yönelik verilen cevaplarda ise; öğretmenlerin \% 83.8'i meslektaşlarının duyarlı olduğunu 
hatta idarenin de çok hassas davrandığını belirtmişlerdir. \% 48.3'ü ise meslektaşlarının yeterli bilgiye sahip olmadıklarını ifade etmişlerdir. Bazı okullarda, idarenin bu konudaki duyarlılığı öğretmenlerin sözlerine belirgin bir şekilde yansıdığı gözlenmiştir.

“.....ihmal olabilir. Çocuk bir haftadır okula aynı kıyafetle geliyor, atlet değişmiyor, leş gibi kokuyordu, üzeri çok pisti..." (Ö8).

“....Cizre'de okulda görev yaparken karşılaştım. Baba ölmüş, anne 4 çocuklu, tekrar evleniyor. 15 yaşında kız öğrenci. Üvey baba her türlü işkenceyi yapmış. Konuşmazdl, içine kapanık, bir tuhaflık olduğu belliydi, ödevlerini yapmazdl, kitap, defter evde unuturdu, üvey baba cinsel tacizde bulunmuş, kız tarım ilacı içerek intihar etti" (Ö29).

Tablo 5. İhmal ve istismarla karşılaşmada sergilenecek tutumlara dair bulgular

\begin{tabular}{lcc}
\hline Vaka ile karşılaşma durumunda sergilenecek tutum & $f$ & $\%$ \\
\hline Çekinmem hemen bildiririm. & 27 & 87 \\
\hline Önce idareye bildiririm. & 13 & 41,9 \\
\hline Önce rehberlik servisine bildiririm. & 7 & 22,5 \\
\hline Önce polise bildiririm & 5 & 16,1 \\
\hline Önce kendim incelerim, durumu anlamaya çalışırım. & 4 & 12,9 \\
\hline Aile ve sosyal politikalar bakanlığına bildiririm. & 3 & 9,6 \\
\hline Aile, kadın, çocuk, engelli ve yaşlı sosyal destek hattının biliyorum & $\mathbf{1}$ & 3,2 \\
\hline
\end{tabular}

Tablo 5'de ihmal ve istismar vakasıyla karşılaşmaları durumunda, nasıl bir tutum sergileyeceklerine yönelik olarak katılımcıların tümü (\%100), net bir şekilde her hangi bir çekince olmadan bildirimde bulunacaklarını ifade etmişlerdir. Bildirimde bulunacakları yer olarak sırasıyla \% 41,9'u önce idareye, \% 22,5'i önce rehberlik servisine, \% 16,1'i önce polise, \% 9,6's1 ise önce aile ve sosyal politikalar bakanlı̆̆ına bildirimde bulunacaklarını ifade etmişlerdir. 4 katılımcı önce kendilerinin durumu değerlendirip sonra bildireceklerini belirtmişlerdir. Görüşmeler sırasında tüm katılımcılara Aile, kadın, çocuk, engelli ve yaşlı sosyal destek ve ihbar hattının telefon numarasını soruldu. Bu hattın kamu spotu olarak televizyonlarda sürekli verildiğini belirtmiş olmamıza rağmen bir katılımcının dışında diğerleri hatırlayamadıklarını ifade etmişlerdir. Dikkat çeken bazı görüşler: 
“...önce kendim anlamaya çalışırım. Çocuk öğretmenine daha çok güvenir. Tehlikeli boyutta ise, polise ya da aile bakanlığına bildiririm, konuyu kapatmam" (Ö29).

“...önce o kişiyi dışarıda ya da okul fark etmez rezil edebileceğim kadar eder, sonra polise bildiririm" (Ö30).

Tablo 6. Çocuk ihmal ve istismarının önlenmesi için önerilere dair bulgular:

\begin{tabular}{lcc}
\hline Çocuk ihmal ve istismarlarını önlemeye yönelik önerileriniz & $f$ & $\%$ \\
\hline Aileler bilgilendirilmeli, eğitilmeli & 23 & 74,1 \\
\hline Öğrenciler bilgilendirilmeli & 17 & 54,8 \\
\hline Öğretmenler bilgilendirilmeli, hizmet içi eğitim verilmeli & 9 & 29 \\
\hline Cezalar attırılmalı & 6 & 19,3 \\
\hline TV yayınları, programlar, afişler yapılmalı, kamu spotları vb. & 5 & 16,1 \\
\hline Aile veya çocuk bildirim için cesaretlendirilmeli & 4 & 12,9 \\
\hline
\end{tabular}

Tablo 6 da ihmal ve istismarların önlenmesine yönelik öğretmenlerin $\% 74,1^{\prime} i$ ailelerin, $\% 54,8$ 'i öğrencilerin bilgilendirilmesi gerektiğini, \%29'u öğretmenlerin hizmet içi eğitim ve seminerler yoluyla bilgilendirilmesi gerektiğini söylemişlerdir. \%19,3'ü cezaların arttırılması gerektiğini, $\% 16,1$ 'i televizyon yayınları, afiş ve kamu spotlarının arttırılmasını, $\% 12,9^{\prime} \mathrm{u}$ ise aile ve çocukların olaya maruz kalmaları durumunda, bildirimde bulunmaları için cesaretlendirilmeleri gerektiğini önermektedirler. Dikkat çeken bazı görüşler:

"Öğretmenlere yönelik etkili seminerler verilmeli. Gerçekten bu işi iyi bilenler tarafından anlatılmalı. Daha önce bir seminere katılmıştım çok etkileyici idi. Çocuk resimleri, anlatılıyordu. Cinsel istismara uğramış bir çocuğun resimleri. Çocuk eteklerini uzun çizmiş, her çizginin bir anlamı varmış meğer" (Ö23).

“...okullarda öğretmenlere ve ailelere seminerler yapılmalı. Fakat seminerler sadece teorik olmamalı, nelerin yapılacă̆ı anlatılmal, teorik olunca kimse ilgilenmiyor, genelde sıkılıyoruz, bitsin diye bakıyoruz" (Ö30).

"....aile eğitim seminerleri yapılabilir. Fakat faydası olacağın düşünmüyorum. Seminerlerin çoğu göstermelik ve sıkıcı, angarya gibi görülüyor" (Ö2). 


\section{Tartışma}

Görüşmeler sırasında, özel eğitim okullarında görev yapan öğretmenlerin, ağırlıklı olarak kadın olduğu gözlenmiştir. Özellikle denge açısından, görüşme için erkek öğretmenler aranmıştır. Okulların tümünde, görüşme yapmak için özellikle özel eğim alan mezunu öğretmenler bulmakta güçlük çekildi. Görüşmelerimiz sırasında bir okulumuzda, özel eğitim alan mezunu öğretmenin olmadığı ifade edilmiştir. Özel eğitim alanı mezunlarına bu alanda ihtiyaç olduğu açıkça görülmektedir. Özel eğitim öğretmeninin bulunmadığı okuldaki tüm öğretmenler, okulda bu konunun idare tarafından çok önemsendiğini, her sabah ilk derste öğrencilerin mutlaka fiziki muayenelerinin yapılıp, fiziksel bir yara izi olup olmadığının kontrol edildiğini ifade etmişlerdir. Ancak, neden bu kadar sıkı denetim yapıldığını sorduğumuzda ise; öğretmen ve idarenin kendilerini korumak amacıyla bunu yaptıklarını ifade ettiler. Görüşmeler sırasında katılımcıların çoğunluğu sorulara kısa cevaplar vermeyi tercih etmişlerdir. Konu dışı anlatımlara daha çok yönelmişlerdir. Detaya yönelik sorulara ise sessiz kalmışlardır. Buda gösteriyor ki; katılımcı ögretmenler bu konuda, ya detaylı bilgiye sahip değiller ya da bu konuda konuşmak istememektedirler.

Araştırmanın 1. alt amacına yönelik sorulara verilen cevaplara göre; katılımcı öğretmenlerin çoğunluğu, çocuk hakları ve çocuk istismarı konusunda bilgi düzeyleri sorulduğunda çalışmaya katılan iki rehber öğretmen hariç diğerlerinin, kendilerini yetersiz gördüklerini, lisans dönemlerinde ve meslek yaşamlarında konuyla ilgili bir ders ya da eğitime katılmadıklarını belirtmişlerdir. Çocuk Koruma Kanunu ve Çocuk Hakları Sözleşmesi sorulduğunda çoğunluğu, duyduklarını fakat içeriği hakkında bilgi sahibi olmadıklarını belirtmişlerdir. Görüşmelerde, konuyla ilgili çok az bilgiye sahip oldukları görülmüştür.

Erol (2007) Okul öncesi öğretmenlerinin çocuklardaki fiziksel istismar belirtilerine ilişkin farkındalıkları belirlemeye yönelik yaptığı çalışmanın sonucuna göre; öğretmenlerin fiziksel istismarı belirlemede yetersiz kaldıkları görülmüştür. Bu bizim bulgularımızla uyuşmamakta, fakat okulöncesi öğretmenlerinin çocuk istismarı konusunda bilgiye ihtiyaçları olduğu sonucu paralellik göstermektedir. Lynn (2008) New Jersey'de öğretmenler üzerinde yaptığı anket çalışmasında; öğretmenlerin çocuk 
ihmal ve istismarı konusunda eğitim aldıkları fakat öğretmenler almış oldukları bu eğitimleri, yetersiz gördüklerini belirtmişlerdir. Ayrıca dikkate alınmayacakları endişesiyle ihmal ya da istismarı bildirmediklerini belirtmişlerdir. Tugay (2008) 400 öğretmenin katılımıyla "Öğretmenlerin Çocuk İstismarı ve İhmaline Yönelik Farkındalık Düzeyleri" konulu tez çalışması yapmıştır. Çalışmaya katılan öğretmenlerin çocuk ihmal ve istismarı ve çocuk korumaya yönelik resmi eğitim almadıkları, öğretmenlerin yarısı kanunlara ve Milli Eğitim politikalarına göre, çoğunluğu ise ahlaki olarak çocuk ihmal ve istismarını bildirmek zorunda olduklarını vurgulamışlardır. Bu sonuçlar, araştırma sonuçlarımızla paralellik göstermekte olup, öğretmenlerin eğitim almalarından ziyade bu eğitimlerin verimliliğinin ve kalıcılığının tartışılması gerektiği görülmektedir.

Dönmez (2009) "okul öncesi öğretmenleri ve velilerin çocuk istismarına ve ihmaline yönelik görüşleri" araştırmasında, 93 okul öncesi öğretmeni ile görüşülmüştür. Elde edilen verilere göre, öğretmenlerin, çocuk ihmali ve istismarı konusunda bilgi sahibi oldukları tespit edilmiştir. Öğretmenler, ihmal ve istismarla ilgili ankette yer alan soruların çoğunluğuna uygun cevapları vermişlerdir. Bu sonuç ise bizim bulgularımızla uygun görünmemektedir. Dönmez (2009) araştırmasında okulöncesi eğitimi öğretmenlerinin çocuk ihmal ve istismarına yönelik aldıkları eğitime dair veri yer almamaktadır. Araştırmada seçenekli ölçek uygulanmıştır. Bizim araştırmamızda açık uçlu sorulardan oluşan görüşme formu uygulandığı için katılımcıların bildiklerini ve düşündüklerini ifade etmekte zorlandıkları düşünülebilir. Ayrıca görüşme sırasında verilen cevaplarda çoğunluğun çocuk istismarından, öncelikli olarak çocuk cinsel istismarını anladıkları anlaşılmıştır.

Kürklü (2011) ilköğretim okulunda çalışan öğretmenlerin çocuk ihmal ve istismarına ilişkin farkındalıklarını belirlemek amacıyla yaptığı çalışmasında, öğretmenlerden hiçbirinin çocuk ihmali ve istismarı ile ilgili eğitim almadığ1 görülürken; çoğunluğunun Çocuk Koruma Kanunu hakkında bilgilendirilmedikleri sonucu, araştırma bulgularıyla benzerlik göstermektedir.

Pala (2011) öğretmen adaylarının, çocuk istismarı ve ihmali konusundaki bilgi ve farkındalıklarını belirlemek amacıyla gerçekleştirdiği araştırmasında, öğretmen adaylarının çoğunluğunun okulda konuyla ilgili eğitim olmadıkları ortaya çıkmıştır. 
Özgül (2015) ilk ve ortaokul öğretmen ve yöneticilerinin, öğrencilerin cinsel istismara uğrama durumunda tutum ve davranışlarını belirleme amacıyla gerçekleştirdiği çalışmasında, Çocuk cinsel istismarı alanında lisans ve yüksek lisans düzeyinde eğitim aldığını söyleyen 1 kişi olmuştur. Bizim araştırmamıza katılan öğretmenlerinde çoğunluğu lisans dönemlerinde konuyla ilgili eğitim almadıklarını belirtmişlerdir. Her iki çalışmada bizim bulgularımızla paralellik göstermektedir. Görüşmeler sırasında katılımclar, konuyla ilgili yeterli bilgiye sahip olmadıklarını belirtmelerinin gerisinde sadece konuyla ilgili eğitim almamaları değil aynı zamanda çocuk ihmal ve istismarının gündemlerinin ilk sırasında olmadığı şeklinde anlaşılmalıdır. Öğretmenlerin çocuk ihmal ve istismarı konusundaki yetersizliklerinin gerisinde çocuk haklarının temelini teşkil eden; çocuğun yüksek yararını gözetme, ayrım gözetmeme, çocuğun görüşlerine sayg1 gösterme ve çocuğun çeşitli gereksinimlerinin olabileceği gibi esasların benimsetilemediği görülmüştür.

Kefeli (2016) “Okulöncesi Öğretmenlere yönelik çalışmasında; Öğretmenlerden \%61.2'i öğrenimleri sırasında çocuk istismarı ve ihmaline yönelik herhangi bir ders almadıklarını vurgulamışlardır. Araştırmaya katılan öğretmenlerden \%96.7'si çalıştıkları kurumda ya da kurum dışında çocuk istismarı veya ihmali ile ilgili bir eğitim almadıklarını ve bu konuda bir hizmet içi eğitime katılmadıklarını belirtmişlerdir. Ö2'nin sınıf yönetimini sağlamak ve çocuklara sözünü dinletebilmek için fiziksel istismar davranışları gösterdiği görülmektedir. Bu bulgular bizim bulgularımızla örtüşmektedir.

Taş (2017) Hacettepe Üniversitesinin farklı bölümlerinde okuyan öğrencilerin, çocuk ihmal ve istismarı hakkındaki bilgi düzeylerinin incelenmesine yönelik yaptığı çalı̧̧mada, çocuk ihmal ve istismarı ile ilgili bilgi alma konusunda çocuk gelişimi öğrencileri \%98 oranında bilgi aldıklarını belirtirken, en düşük oran ise \%23.4'le sınıf öğretmenliği olmuştur. Üniversite yaşamında konuyla ilgili konferanslara katılma oranı açısından, okulöncesi, çocuk gelişimi, sosyal hizmet, sınıf öğretmenliği, psikoloji ve sosyoloji bölümü öğrencileri arasından ilk sırada sosyal hizmet, ikinci sırada ise çocuk gelişimi bölümü öğrencileri, en son sırada ise sınıf öğretmenliği bölümü öğrencileri olmuştur. Bizim araştırmamızda da katılımcı öğretmenlerin çoğunluğunu sınıf 
öğretmenliği alnından özel eğitime geçmiş olanlar oluşturduğundan bizim elde ettiğimiz bulguları desteklemektedir.

Walsh ve Bridgstock (2005) tarafında Avustralya'da yapılan bir araştırmada ise ülkemizde yapılan araştırma bulgularının aksine katılımcıların \%93.3'ü çocukları korumaya yönelik eğitimler aldıklarını belirtmişlerdir. $\mathrm{Bu}$ yönüyle mevcut çalışmamıza ters bulgular elde edilmiştir. Bunun sebebi ise Avusturalya'da çocukları korumaya yönelik zorunlu bir hizmet öncesi eğitimin var olmasıdır.

Araştırmanın 2. alt amacına yönelik okulunuzda konuyla ilgili ne gibi etkinlik ya da çalışma yapıldığına dair soruya verilen cevaplara göre; öğretmenlerin çoğunluğu tüm meslek yaşamlarını da kastederek hiç bir etkinlik ya da çalışmaya katılmadıklarını ifade etmeleri, bu konuda ciddi ve etkili çalışmalara ihtiyaç olduğunu göstermektedir. Ancak bazı öğretmenlerin belirttiği gibi yapılacak çalışmaların iyi planlanması, öğretmenlerin karar sürecine katılıp çalışmayı sahiplenmeleri, etkinliklerde sunum yapan kişilerin uzman ve doğru kişi olmaları ve teorik bilgilerin yanı sıra uygulamaya da önem verilmesi, çalışmaların etkililiğini arttıracaktır. Ayrıca rehberlik öğretmenlerinin çocuk istismarı ile ilgili ailelere yönelik yaptıkları toplantıların sönük ve katılımın yetersiz olduğunu vurgulamış olmaları aileye ulaşma konusunda da yeni ve etkili yolların bulunması gerektiğini göstermektedir.

Özgül (2015) ilk ve ortaokul öğretmen ve yöneticilerinin, öğrencilerin cinsel istismara uğrama durumunda tutum ve davranışlarını belirleme amacıyla gerçekleştirdiği çalışmasında, bir eğitimci, bu konuda 2 günlük Hizmet içi Eğitim aldığını söylemiş ancak aldığı eğitimin niteliksiz olduğunu söylemiştir. Bu sonuçlar bizim araştırma sonuçlarımızla paralellik göstermekte olup öğretmenlere yönelik olarak gerçekleştirilecek olan bu tür bilgilendirici etkinliklerin daha planlı ve verimli olacak şekilde düzenlenmesi olumlu sonuçlar verecektir.

Araştırmanın 3. alt amacına yönelik sorulara verilen cevaplara göre; katılımcı öğretmenler, çocuk istismarının nedenleri konusunda çoğunluğu belirgin bir şekilde aileden kaynaklandığını; ailenin yoksulluğu, eğitim yetersizliği, çocuğa karşı ilgisizliği, aşırı baskıcı oluşunu belirmişlerdir. Özel eğitim okulunda görev yapmaları sebebiyle, özellikle engelli çocukların daha fazla istismara açık olduklarını belirtmişlerdir. Bu sonuca paralel olarak Bulut ve Karaman (2018) “Engelli Bireylerin Cinsel, 
Fiziksel ve Duygusal İstismarı" araştırması sonuçlarına bakıldığında engelli bireylerin istismar konusunda risk altında olduğu görülmektedir. Araştırmamızda katılımcı öğretmenlerden biri, özel eğitim okullarının her yerinde kamera olduğunu engelli çocuklara yönelik istismar yapılamayacağını, bir başka öğretmen ise günümüzde engelli çocuklara karşı duyarlılığın arttığını, eskiye göre bu çocukların daha az istismara uğrayabileceklerini belirtmiştir. Katılımcılar istismarın aile ve yoksulluk temelli olduğunu belirtmişlerdir. Ayrıca yoksulluğun, aileden kaynaklanan nedenler arasında ön plana çıkması, okul yönetimlerinin bu konuda yapılabilecekleri, düşünmeleri gerektiğini göstermektedir. Katılımcıların istismarın nedenleri konusunda daha çok cinsel istismarı düşünerek cevap verdikleri anlaşılmaktadır. Öğretmelerin ihmal ve istismarın çeşitleri ve boyutları konusunda eğitime ihtiyaç duydukları görülmektedir. Bazı katılımcıların değerlerden uzaklaşılmasını, istismarın nedenleri arasında belirtmiş olmaları, olayın ahlaki ve inançsal boyutunun da göz ardı edilmemesi gerektiğini göstermektedir.

Araştırmanın 4. alt amacına yönelik sorulara verilen cevaplara göre; katılımcılar, ihmal ya da istismarı nasıl anlayacakları, belirtileri sorulduğunda, fiziksel istismarı, darp izi, çizikler, vücuttaki yaralar sebebiyle daha kolay anlayabileceklerini, cinsel istismar konusunda çocukların, çekingen, içe kapanık ya da hırçınlık gibi davranışlarında ani değişikliklerin olacağını ifade etmişlerdir. Katılımcıların istismarın belirtileri ile ilgili verdikleri cevaplar, tanılama konusunda sınırlıda olsa bilgiye sahip olduklarını göstermektedir. Fakat katılımcıların eğitimci olması sebebiyle, çocuk ihmal ve istismarı gibi önemli ve kapsamlı bir konuda çok cılız ve sınırlı ifadelerde bulunmaları yetersiz ve eğitimimiz açısından problemli bir durumdur. Eğitimcilerin, daha geniş bakış açılarına sahip olmaları için bilginin ötesinde, konuya ilgilerinin çekilmesi daha gerekli görülmektedir. Birçok katılımcı öğretmen, vakayla hiç karşılaşmadıklarını belirtmiş bu sebeple çok bilgisinin olmadığını söylemiştir. Bu ise özellikle risk kapsamında ön sıralarda bulunan engelli çocukların eğitim gördükleri özel eğitim okullarında görevli öğretmenlerden beklenen bir tutum değildir. Katılımcı ifadelerinden çocuklara ilk derste sadece fiziki kontroller yapıldığı anlaşılmaktadır.

Araştırmanın 5. alt amacına yönelik sorulara verilen cevaplara göre; katılımcı öğretmenler vaka ile karşılaşma durumunda, bildirimde 
bulunacakları ve öncelikli olarak idareye bildirecekleri görülmektedir. Fakat böyle bir durumda nasıl bir yol izleyecekleri konusunda yeterli ve sağlıklı bilgiye sahip olmadıkları anlaşılmaktadır. Yılmaz (2015), bir hastanede çalışan hemşirelerin çocuk ihmal ve istismarına yönelik bilgi ve yaklaşımlarını belirlemek amacıyla yaptığı araştırmasında Katılımcıların \%96,1'i çocuk ihmal ve istismarı şüpheli bir durumda bildirim yapacaklarını belirtmişlerdir. Sağır (2013) tarafından gerçekleştirilen çalışmada, araştırmaya katılan öğretmenlerin \%98'i, Kürklü (2011) tarafından yapılan araştırmada öğretmenlerin \%99.2'si, Pala (2011) tarafından yapılan çalışmada öğretmenlerin \%96.4'ü, Tugay (2008) tarafından gerçekleştirilen çalışmada öğretmenlerin \%85.2'si vicdanen çocuk ihmal ve istismarını bildirmekle yükümlü olduklarını belirtmişlerdir.

Kürklü (2011) ilköğretim okulunda çalışan öğretmenlerin çocuk ihmal ve istismarına ilişkin farkındalıklarını belirlemek amacıyla yaptığı çalışmasında, Öğretmenlerin çocuk ihmal ve istismarını tespit ettiklerinde bildirim yapacakları kurumların başında okul yönetimi gelmektedir. Sağır (2013) tarafından yapılan araştırmada öğretmenler ilk olarak bildirimde bulunacakları yer olarak okul yönetimini, en son bildirimde bulunacakları yer olarak da okul aile birliğini belirtmişlerdir. Pala (2011) tarafından yapılan araştırmada ise ilk olarak bildirimde bulunacakları yerin olarak okul yönetimi ikinci olarak da Sosyal Hizmetler Müdürlüğü olarak belirtmişlerdir. Çalışmada lise öğretmenlerinin, okullarında çocuk ihmal ve istismarının hiç görülmediği inancında oldukları bulunmuştur. $\mathrm{Bu}$ bulgular, araştırmamızda elde edilen bulguları destekler niteliktedir. Bizim çalışmamızda da katılımcıların çoğunluğu vaka ile hiç karşılaşmadıklarını belirtmişlerdir. Özellikle kamu spotu şeklinde ekranlarda sürekli gösterilen, aile, kadın, çocuk, engelli ve yaşlı sosyal destek ve ihbar hattının V şeklinde 1şıklandırılarak gösterilen 183 olan numarasını sadece bir kişinin söyleyebilmiş olması, bildirimde bulunmaları konusunda endişe verici bir durum olarak görülebilir. Bildirimde bulunacakları yerlerin başında okul yönetiminin gelmesi hem öğretmenlerin hem de okul idaresinin vaka durumunda izlenecek yolu ve yapılacakları doğru şekilde bilmeleri, bildirimde bulunmayı kolaylaştıracağı görülmektedir. Kenny (2004) tarafından yapılan araştırma sonucunda öğretmenleri birçoğu çocuk ihmal ve istismarını bildirim konusunda kendilerini zorunlu hissetmemektedirler. Öğretmenler yanlış 
yapma korkusunun, bildirmeme kararı almada en önemli faktör olduğunu belirtmişlerdir. Bu sonuç, bizim bulgularımızla ters düşmektedir.

Araştırmanın 6. alt amacına yönelik sorulara verilen cevaplara göre; özel eğitim okullarında görevli katılımcı öğretmenler, ihmal ve istismarların önlenmesi için sırayla \%73.1 ailelere eğitim verilmesi, \%53.6 öğrencilerin eğitilmesi, \%26.8 öğretmenlere eğitim verilmeli, \%21.9 cezaların arttırılması, \%19.5 televizyon ve farklı yayınlarla bilgilendirmeler yapılması gerektiğini belirtmişlerdir. Öğretmenler için verilecek olan seminer vb çalışmaların göstermelik olmayıp daha işlevsel ve etkili olacak şekilde düzenlenmesi gerektiği anlaşılmaktadır. Ayrıca medya ve diğer iletişim araçlarının da bu konuda kamuoyuna ulaşacak özellikte kullanılması gerektiği görülmektedir. Çocuklarla ilgili tüm sorunlarda olduğu gibi istismar sorunlarının çözümünde de aile eğitimi ön plana çıkmaktadır.

Kefeli (2016) “Okulöncesi Öğretmenlerinin Çocuk İstismarı ve İhmali ile Kurum Personelinin Konuya İlişkin Görüşleri" konulu çalışmasında, okul öncesi öğretmenlerin ihmal ve istismarın önlenmesine yönelik önerileri; Ailelere eğitim verilmeli \% 48.3, çocuklara eğitim verilmeli \% 38.7, öğretmenlere eğitim verilmeli \% 22.5, tüm toplum bilinçlendirilmeli \%16.1, yaptırımı büyük ve caydırıcı cezalar verilmeli \% 6.4, televizyonda bilgi verici programlar olmalı \% 6.4 şeklinde olup bu bulgular, bizim çalışmamızdaki bulgularla örtüşmektedir.

\section{Sonuç}

Araştırmada, özel eğitim kurumlarında çalışan öğretmenlerin çocuk ihmal ve istismarına yönelik bilgi ve farkındalık düzeyleri ile kişisel bilgi formunda yer alan; cinsiyet, yaş, medeni durum, anne-baba olma durumu, deneyim ve mezun olunan lisans alanı arasında anlamlı bir ilişki olmadığı sonucuna ulaşılmıştır.

1. Birinci alt amaç doğrultusunda; çocuk hakları, ÇKK, çocuk ihmal ve istismarı konusundaki bilgi durumları, yeterlilik algıları ve konuyla ilgili bilgi edinme yollarına bakıldığında katılımcı öğretmenlerin çoğunluğu, lisans döneminde konuyla ilgili yeterli ve kalıcı dersler almadıkları görülmüştür. 
2. İkinci alt amaç doğrultusunda; çalıştıkları kurumlarda çocuk ihmal ve istismarına ilişkin yapılan çalışmalara katılımcıların çok azı bilgilendirici çalışmalara katılmışlar, katılanların ise bu çalışmaları, etkili ve verimli bulmadıkları anlaşılmaktadır.

3. Üçüncü alt amaç doğrultusunda; çocuk ihmal ve istismarının nedenlerine yönelik görüşleri incelendiğinde katılımcıların tümü ihmal ve istismarlarm gerisinde aile temelli nedenlerin; ailenin yaşadığ1 yoksulluğun, eğitim seviyesinin düşüklüğünün, çocuğa karşı ilgisizliklerinin, parçalanmış ailenin olduğunu düşündükleri görülmüştür. İstismarın önemli bir nedeni olarak da çocuğun engelli olmasını gördükleri söylenebilir.

4. Dördüncü alt amaç doğrultusunda; ihmal ve istismarı tanılama ve meslektaşlarının konuya duyarlılıkları konusunda, öğretmenlerin çoğunluğunun vakayla hiç karşılaşmadıkları halde, ihmal ya da istismarın fiziksel ve psikolojik belirtileri konusunda genel ve yüzeysel bilgilere sahip oldukları söylenebilir. Katılımcılar meslektaşlarının, ihmal ve istismarla ilgili yeterli bilgiye sahip olmadıklarını fakat konuya duyarlı olduklarını düşündükleri görülmektedir.

5. Beşinci alt amaç doğrultusunda; araştırmada elde edilen en net sonuçlardan biri; öğretmenlerin ihmal ve istismar vakasıyla karşılaşmaları durumunda doğrudan bildirimde bulunacakları ve öncelikli olarak okul idaresine bildirecekleri anlaşılmaktadır. Ayrıca özel eğitim okullarında çalışan öğretmenlerin, çocuk ihmal ve istismarına duyarlılık konusunda okul yönetimine güvendikleri söylenebilir.

6. Altıncı alt amaç doğrultusunda; ihmal ve istismarın önlenmesine yönelik öneriler konusundaki bulgulardan hareketle katılımcıların çoğunluğu hem ailelerin hem de öğrencilerin konuyla ilgili olarak bilgilendirilmeleri gerektiğini düşünmektedirler. Katılımcıların bir kısmı öğretmenler içinde eğitimler verilmesi gerektiğini fakat bu eğitimlerin etkili olması durumunda sonuç alınacağını düşündükleri anlaşılmaktadır. Ayrıca istismar suçlarına yönelik cezaların etkili ve caydırıcı olmasının, bildirim konusunda tarafların cesaretlendirilmesinin, medya ve diğer iletişim araçlarının da ihmal ve istismar konusunda kamuoyuna ulaşacak özellikte 
kullanılmasının ihmal ve istismarları önleyeceğini düşündükleri söylenebilir.

\section{Öneriler:}

1. Öncelikle, risk kapsamında değerlendirilen ailelere (parçalanmış aile, üveylik ilişkisi olan aile, baba ya da annenin olmadığı veya annenin çalıştığı aile, yoksul aile vb.) ihmal ve istismarla ilgili eğitimler verilebilir.

2. Üniversitelerin, öğretmen yetiştiren programlarının tümünde, zorunlu ders olarak "İnsan ve Çocuk Hakları" dersi konulabilir.

3. Özel eğitim okullarında çocuk ihmal ve istismarı konusunda ailelerle yapılacak olan bilgilendirme toplantılarının daha farklı yollarla; konusu çocuk, çocuk sevgisi, çocuk eğitimi veya engelli bireylerin başarı hikâyelerinin olduğu sinema ve tiyatro gösterisi gibi etkinlikler şeklinde yapılabilir. Etkinliklere konuşmacı olarak sahadan; çocuk şubeden emniyet görevlisi, çocuk mahkemelerinden yargı mensubu, çocuk yuvasından, sevgi evlerinden görevli kişiler davet edilebilir.

4. Çocuk ihmal ve istismarı ile ilgili öğretmenlere yönelik gerçekleştirilecek hizmet içi eğitim, seminer vb. çalışmalarda öncelikli olarak "çocuk sevgisi, çocuk hakları, çocuğun anlamı ve değeri" konuları işlenebilir.

5. Öğretmenlerin, vaka ile karşılaşma ya da şüphe durumunda nasıl bir yol izleyecekleri konusunda, internet üzerinden sistemler geliştirilebilir.

6. İhmal ve istismar suçlarına yönelik gerçekleştirilecek etkinlik ve yasal düzenlemeler konusunda, öğretmen görüşleri araştırılabilir.

7. Okullarda çocuk hakları, çocuk ihmal ve istismarı ile ilgili öğretmenler için düzenlenecek olan etkinliklerin daha verimli ve etkili olabilmesi için neler yapılabileceği konusunda, öğretmen görüşleri araştırılabilir. 


\title{
EXTENDED ABSTRACT
}

\section{Examination of The Knowledge And Awareness Levels of Teachers Working in Special Education Institutions About Child Neglect and Abuse}

*

\author{
Arif Toydemir - Erkan Efilti
}

Selçuk University - Necmettin Erbakan University

The future of societies depends on the healthy development and education of children by physical, spiritual, moral and intellectual. It is generally accepted that children should be educated and their physical and mental health should be protected so that societies can settle their future on solid and healthy foundations (Kocaer, 2006). Each child should be considered as independent individuals, benefit from economic and social rights as much as possible, and more importantly, they should not be deprived of fundamental human rights and freedoms on the basis of all policies and practices to be developed for children (Aral \& Gürsoy, 2001; Kocaer, 2006). When the value of the child in ancient times is compared with present value, the historical development of children's rights can be summarized as follows; the child, who can be freely exploited, alienated and abandoned, even considered as a killable "object", has experienced the adventure of transforming it into a "subject" with competent rights and personality (Çelik, 2014). Many legal arrangements have been made in national and international fields with the aim of protecting the best interests of the child. These arrangements intended to ensure the rights and freedoms of the child. However, despite all these legal arrangements, it is observed that child abuse and neglect continue (Taş, 2017). Neglect and abuse cases are leading problems experienced by today's children. While the child abuse ratio ranges from $1 \%$ to $10 \%$ in the world, it ranges from $10 \%$ to $53 \%$ in Turkey (Yıldırım Doğru et. al., 2014). It was made possible by the Geneva Declaration of the Rights of the Child (1924) that the children were different from adults and treated as an individual, and their survival, development and protection as the basic principle for the first time in the international context. The declaration later became an international 
covenant as "UN Convention on the Rights of the Child (UNCRC)". One of the most important features of the covenant is the acceptance of the child as "the subject of rights" (Usta, 2012).

One of the groups within the scope of children's rights issues is children with difficult conditions. These are street children, abused children, children with disabilities, children exposed to disasters and immigrants (Polat, 2001). If the child has a chronic discomfort or an inherent obstacle, it is difficult for parents to accept the child. These situations cause parents to abuse the child (Hoşoğlu, 2009). It is known that children with disabilities who are more disadvantaged than others and who have special education needs are at the top of the risk groups in terms of neglect and abuse. Prevention of child neglect and abuse is uneasy, complex and time consuming. All social layers must provide support. In this respect, it is vital to increase the awareness of the teachers who are in close interaction with children in terms of determining the situation and intervening in the early period (Tugay, 2008). In this study, the main problem of this study is to examine the knowledge and awareness levels of teachers working in special education institutions about child neglect and abuse.

The purpose of this study is to reveal the knowledge and awareness levels of teachers working in special education institutions about child neglect and abuse by a qualitative study. The research questions of the study are as follows: What are the knowledge levels of teachers working in special education institutions about neglect and abuse? Where and how did they obtain the information they had about neglect and abuse? What kind of studies was done in their institutions? How do they realize the signs of neglect and abuse? What are their thoughts on the causes of abuse? How will they behave in the event of a case? What are their suggestions for preventing abuse?

\section{Method}

In this study, qualitative research method was used in accordance with the purpose of the research. Qualitative research is a research method or model in which data collection tools such as observation, interview and document analysis are used, and events and perceptions are appropriately presented. Data collection, analysis, interpretation and evaluation in 
qualitative research are not independent of the researcher's personal evaluations (Yıldırım \& Şimşek, 2013). The sample consisted of 31 teachers (18 female and 13 male) working in the special education schools and centers in the central districts of Konya. In this research, the purposed sampling method was used. Interview technique which is frequently used in qualitative research was used as data collection tool. The interview is a question and answer communication process between the researcher and the participants in the study group. This process is often carried out face to face, but it can also be carried out by various communication tools. The interview form used in the research consisted of two parts: personal information form and semi-structured interview form. Semi-structured interview form consisting of open-ended questions:

1. What is your knowledge level about child rights, Child Protection Law, and Convention on the Rights of the Child, child neglect and abuse? Do you consider yourself adequate in this regard? How did you get the information you had?

2. What kind of studies is conducted in your school or institution for child neglect and abuse?

3. What are the reasons for the neglect and abuse of children?

4. How can you realize if a child or student is neglected and abused? What are the symptoms?

5. What do you think should be done to reduce child neglect and abuse? What are your suggestions?

Descriptive analysis was used to analyze the data obtained through interviews. The data obtained from the participants were collected in advance or in the themes identified during the research, rearranged systematically to form a unity, and depicted into tables to make them more comprehensible.

\section{Results}

93.5\% of the participants stated that they did not have enough knowledge about child neglect and abuse, and $16.1 \%$ of them stated that they participated in the course or education activities related to child neglect and abuse in the university life. $87 \%$ of the participants stated that they did not have enough information about the Child Protection Law and the 
Convention on the Rights of the Child, and $32.2 \%$ of them stated that they participated in activities such as training and seminar on the subject during their professional life.

$90 \%$ of the teachers stated that there was no study in their institutions related to child neglect and abuse, and $29.2 \%$ of them stated that the counseling service provided the students and especially the parents on the subject.

All of the participants (100\%) consider that the first cause of child neglect and abuse is the poverty of the family, the low level of education and the indifference towards the child. The child's disability is in the second cause (58\%), and it is followed by moral corruption, inappropriate television programs for children, internet addiction, the child's introvertedness and shyness, and inadequate punishments.

$93.5 \%$ of the teachers stated that they could realize the physical symptoms of abuse, and $77.4 \%$ of them could realize the psychological symptoms of abuse in diagnosing the symptoms of child neglect and abuse. During the interviews the question was asked: "Have you ever encountered a case?". In addition, $58 \%$ of teachers stated that they could not provide more information because they did not encounter a case. $83.8 \%$ of them stated that their colleagues were sensitive to the subject, and $48.3 \%$ of them stated that their colleagues did not have sufficient knowledge on the subject.

In the case of child neglect and abuse, all participants (100\%) stated that they would report definitely without any reservations, especially to the school administration.

When asked about their suggestions for the prevention of abuse and abuse, the participants stated that families $(71.1 \%)$, students $(54.8 \%)$ and teachers $(29 \%)$ should be informed through training and seminars.

\section{Discussion}

In this study, it was perceived that teachers working in a special education institution did not have sufficient knowledge about rights of the child, Child Protection Law, child neglect and abuse, and they did not get sufficient and permanent education in their universities and institutions. Lynn (2008) concluded that teachers were educated on the subject of child 
neglect and abuse but they considered these trainings as inadequate. Tugay (2008), Kürklü (2011), Özgül (2015) and Kefeli (2016) revealed that teachers were not educated about child neglect and abuse. Özgül (2015) stated that an educator received a two-day in-service training on the subject, but it was unqualified. These results show that teachers need more effective training on children's rights, neglect and abuse. These trainings will be effective if they are initiated in university education. In a study conducted by Walsh and Bridgstock (2005) in Australia, contrary to the research findings in Turkey, participants stated that they had received training to protect children. The reason is that a compulsory pre-service training is provided to protect children in Australia.

Participants of the study consider that there are family-based reasons on the basis of neglect and abuse. Participants also consider the child's disability as a risk. Bulut and Karaman (2018) concluded that individuals with disabilities are at risk for abuse. Besides, they concluded that priority should be given to the families that can be evaluated within the scope of risk in the studies to be conducted about the abuse.

It is considered that the knowledge and equipment of the teachers is superficial in the diagnosis of neglect and abuse, and this will make the intervention and legal notification difficult. Participants stated that they would report in case of encounter with a case. However, considering the fact that they have never encountered any case and they have not made any notifications until now, it is not certain that these attitudes can turn into behavior. Kürklü (2011) and Yilmaz (2015) revealed that participants will report and feel the responsibility of reporting.

In order to prevent neglect and abuse of children, students and teachers should be educated, especially families, but these trainings should be planned effectively and efficiently. In addition, the punishment for the crime of abuse should be effective and deterrent, and the mass media should be used correctly to inform the public and raise awareness on the subject. The suggestions of pre-school teachers for the prevention of neglect and abuse support this requirement: respectively families, children and teachers should be educated, and the public should be informed. 


\section{Kaynakça / References}

Akbulut, Y.(2010). Sosyal bilimlerde araştırma yöntemleri. Eskişehir: Anadolu Üniversitesi Açık Öğretim Fakültesi Yayınları.

Ataman, A. (2005). Özürlü çocuklar ve özel eğitime giriş (6. Baskı) Ankara: Gündüz Yayıncılık.

Bulut, S. \& Karaman, H. B. (2018). Engelli bireylerin cinsel, fiziksel ve duygusal istismarı. Ankara Üniversitesi Ĕ̆itim Bilimleri Fakültesi Özel Eğitim Dergisi, 19(2), 277-301. doi: 10.21565/ozelegitimdergisi.382961

Çelik, T. (2014). Türkiye'de çocuk olmanın tarihi: Doğan kardeş dergisi. Hasan Ersel. Kazım Taşkent, Yapı Kredi ve Kültür Sanat. İstanbul: Yapı Kredi Yayınları.193-232.

Dönmez, E. (2009). Okul öncesi eğitimi öğretmenleri ve velilerin çocuk istismarına ve ihmaline yönelik görüşleri. Yayımlanmamış Yüksek Lisans Tezi, Selçuk Üniversitesi Sosyal Bilimler Enstitüsü. Konya.

Erol, D. (2007). okulöncesi eğitim kurumlarında görev yapan öğretmenlerin çocuklardaki fiziksel istismar belirtilerine ilişkin farkındalıkları (Eskişehir İl Örneği). Yayımlanmamış Yüksek Lisans Tezi, Anadolu Üniversitesi Eğitim Bilimleri Enstitüsü, Eskişehir.

Güler, N., Uzun, S., Boztaş, Z., Aydoğan, S.(2001). Anneleri tarafından çocuklara uygulanan duygusal ve fiziksel istismar/ihmal davranışı ve bunu etkileyen faktörler. C. Ü. Tıp Fakültesi Dergisi, 24 (3), $128-134$

Hoşoğlu, R.(2009). Engelli öğrencilerin istismar ve ihmal düzeyleri. Yayımlanmamış Yüksek Lisans Tezi, On Dokuz Mayıs Üniversitesi Sosyal Bilimler Enstitüsü, Samsun.

Kefeli, H.(2016). Okul öncesi öğretmenlerinin çocuk istismarı ve ihmali davranışları ile kurum personelinin konuya ilişkin görüşleri. Yayımlanmamış Yüksek Lisans Tezi, Ankara Üniversitesi, Eğitim Bilimleri Enstitüsü Ankara.

Kenny MC. (2004). Teachers' attitudes toward and knowledge of child maltreatment. Child Abuse \& Neglect, 28(12), 1311-1319. 
Kocaer, Ü. (2006). Hekim ve hemşirelerin çocuk istismarı ve ihmaline yönelik farkındalık düzeyleri. Yayımlanmamış Yüksek Lisans Tezi, Marmara Üniversitesi Sağlık Bilimleri Enstitüsü, İstanbul.

Kürklü A. (2011). Öğretmenlerin çocuk istismar ve ihmaline yönelik farkındalık düzeyleri. Yayımlanmamış Yüksek Lisans Tezi, Afyon Kocatepe Üniversitesi, Sağlık Bilimleri Enstitüsü, Afyon.

Lynn, K. (2008). Evaluating potential obstacles to mandated reporting of child abuse and neglect by educators in a suburban public school district (Doctoral dissertation). Available from Pro Quest Dissertations and Theses database. (UMI No. 3370298)

McKee, B.E., Dillenburger, K. (2009). Child abuse and neglect: training needs of student teachers. International Journal of Educational Research, 48, 320-330

Özgül, D.(2015). Öğrencilerin cinsel istismara uğrama durumunda ilk ve ortaokullarda çalışan öğretmen ve okul yöneticilerinin tutum ve davranışları. Yayımlanmamış Yüksek Lisans Tezi, İstanbul Üniversitesi Sosyal Bilimler Enstitüsü, İstanbul.

Pala, B.(2011). Geleceğin öğretmenlerin çocuk istismar ve ihmali konusunda bilgi ve farkındalık düzeyleri. Tıpta Uzmanlık Tezi, Eskişehir Osman Gazi Üniversitesi Tip Fakültesi, Eskişehir.

Polat O. (2001). Çocuk hakları ve adli tıp. Adli Tıp Dergisi, , 15(3), 53-75.

Sağır, M. (2013). Okul öncesi ve sinıf öğretmenlerinin çocuk istismarı ve ihmaline yönelik görüşleri ve farkındalık düzeyleri (Kayseri ili örneği), Yayımlanmamış Yüksek lisans tezi, Erciyes Üniversitesi Eğitim Bilimleri Enstitüsü, Kayseri.

Taş, A.(2017). Hacettepe üniversitesi öğrencilerinin çocuk ihmal ve istismarn hakkındaki bilgi düzeylerinin incelenmesi. Yayımlanmamış Yüksek Lisans Tezi, Hacettepe Üniversitesi Sosyal Bilimler Enstitüsü, Ankara.

Tugay, D.(2008). Öğretmenlerin çocuk istismarı ve ihmaline yönelik farkındalık düzeyleri. Yayımlanmamış Yüksek Lisans Tezi, Marmara Üniversitesi Sağlık Bilimleri Enstitüsü, İstanbul.

Usta, S. (2012). Çocuk hakları ve velayet. İstanbul: On İki Levha Yayıncılık. 
Walsh K, Bridgstock R, Farrell A, Schweitzer R. (2005). Critical factors in teachers' detecting and reporting child abuse and neglect: Implications for practice. Queensland:Queensland University of Technology.

Yıldırım Doğru, S., Durmuşoğlu Saltalı, N.,Konuk Er, R. ve Budak, O.(2014). (Ed. S. Yıldırım Doğru) Çocuk hakları ve koruma. Ankara: Eğiten Kitap.

Yıldırım, A., Şimşek, H. (2013). Sosyal bilimlerde nitel araştırma yöntemleri ( 9. Bask1). Ankara: Seçkin Yayıncılık.

\section{Kaynakça Bilgisi / Citation Information}

Toydemir, A. ve Efilti, E. (2019). Özel eğitim kurumlarında çalışan öğretmenlerin çocuk ihmal ve istismarına ilişkin bilgi ve farkındalık düzeylerinin incelenmesi. OPUS-Uluslararası Toplum Araştırmaları Dergisi , 10(17), 490-519. DOI: 10.26466/opus.518214 